\title{
European urban polycentrism: a multiscale typology
}

\section{Céline Rozenblat, Lausanne}

\section{Introduction}

It is commonly argued that while towns and cities, and capital cities in particular, do constitute the principal source of diffusion and growth - as was seen with development poles initiated during the 1960s (Perroux 1955), they also cause abrupt spatial ruptures with their surroundings. An important reason for the discontinuities observed in per capita GDP (gross domestic product) may be found in the fracture between capital cities and their hinterlands (European Spatial Planning Observation Network 2006; FALUdi 2004; Faludi \& Waterhout 2002; Rozenblat 2004). These discontinuities can reach proportions similar to those produced by ruptures at international frontiers. In fact, of course, cities constitute contact portals into the international sphere in exactly the same way as national boundaries do. Cities develop a long-distance reticular proximity which allows them to uphold intensive relationships supporting growth of economies of networking. Although they may integrate their own urban economies in this manner, it can also lead to isolation from their own national regions (CAstells 1998; Pumain 1997; Sassen 1991). Thus, rather than constituting a factor of homogenisation, it is possible that cities actually contribute towards other developmental aspects of European territorial cohesion by means of the various types of interdependence that are woven in the threads of urban networks.

\section{The European urban framework}

Taken all together, European countries (except those issued from the defunct USSR) constituted an urban fabric that, in 1990, consisted of 5,200 urban centres with a population of more than 10,000 inhabitants (CATtan et al. 1999; Moriconi-Ebrard 1994). The spatial organisation of that fabric offered very unequal opportunities for interaction at different levels of geographical influence.

\subsection{Local urban frameworks}

Zones with high city density in which cities are separated from each other by less than $25 \mathrm{~km}$ are plentiful along the European dorsal axis (Fig. 1A). It stretches from the north of England (the region of Newcastleupon-Tyne) to Sicily, interrupted only by the English Channel and the Alps (Rozenblat 1995). The margins situated to either side of this zone of high urban den- sity, however, present a very different aspect. To the east, and particularly in Eastern Europe, stretches a continuous network of regularly spaced towns. While to the west, in France and Spain groups of proximate urban centres are sparse, although some networks do distinguish themselves along river valleys like those of the Seine or the Rhone, as well as relatively compact networks in Andalusia, the Basque Country and around Vigo or Porto. At a larger network scale (between 25 and $50 \mathrm{~km}$ ) the distribution of these inequalities of density is confirmed.

The most heavily populated cities (those with more than 100,000 inhabitants) present us with the apex of the urban hierarchy in a more selective schematic (Fig. 1B). Similar continuities of high urban density may also be found along the European dorsal axis and in its margins. Other networks, however, which are less dense because they are dominated by large cities, are discovered at this scale, located notably along a diagonal axis running from Poland to Bulgaria. Two east-west continuities link this diagonal to the dorsal axis: in the north through Germany, and in the south via Slovenia. Another diagonal axis, but in this case constituted by an absence of density, runs northwest to southeast from Germany to the Balkans. Its orientation in relation to the European dorsal axis is quasi-symmetrical with another, better known, «axis of emptiness» that crosses France and Spain southwest to northeast.

A comparison of these three different grid levels reveals the permanence of urban densities at the different levels of the urban hierarchy. The scale-free character of urban networks can be understood as the result of the historical constitution of local and regional urban networks (CHRISTALLER 1933) which served as the basis for the subsequent development of national and international urban networks (OFFNER \& Pumain 1996; Pumain 1997; Rozenblat \& Pumain 2007). Building on this, it is possible to inquire into interregional differences of settlement systems and their capacity for adaptation and development within the new networks of exchange and communication.

\subsection{Regional forms of settlement}

The division of Europe into regions - the product of political and/or administrative compromises - does not necessarily coincide with the geographical logic of urban networks. Nevertheless, it would seem useful to maintain this division in order to generate within its framework those indicators which characterize the structure of urban networks so as to be able to compare them to the indicators of economic devel- 


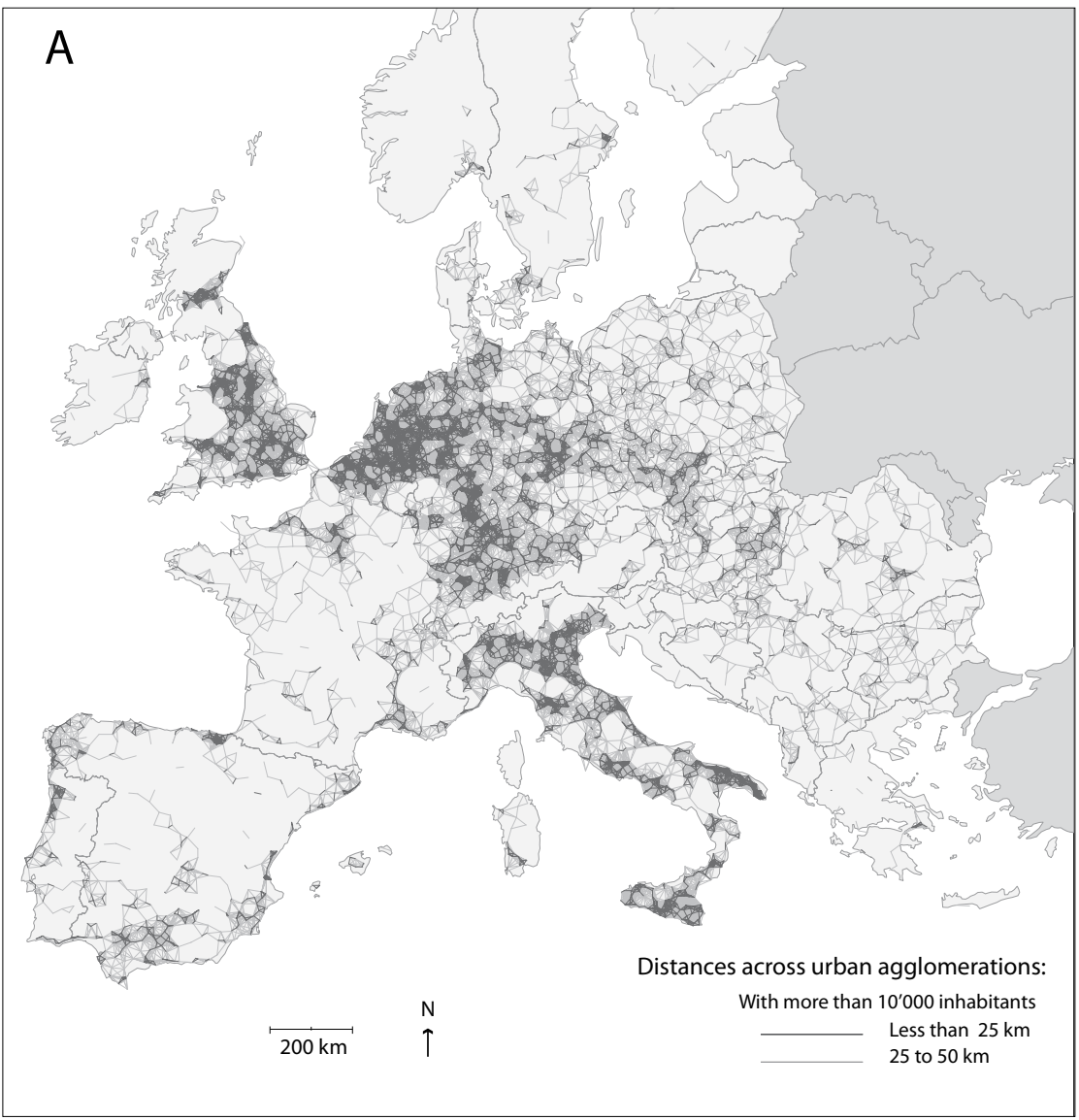

Fig. 1A: European urban framework according to cities with more than 10'000 inhabitants Europäisches Städtesystem nach Städten mit mehr als 10'000 Einwohnern

Trame urbaine européenne selon les villes de plus de 10'000 habitants

Data source: Fr. MoRICONI-EBRARD, 1994; georeferencement, modelization, cartography: C. Rozenblat

opment. As long ago as 1976, ETIENNE JuILLARD and HENRI NONN postulated a typology of European urban regions based on their study of medium-range relationships between urban centres and their zones of influence in terms of urban centrality functions (services to and the framing of territories). This investigation can be carried out at a lower cost by examining, as done here, morphological aspects of the urban network. These aspects are understood here to be the long-term consequences of the effect of territorial and functional competition between urban centres (KüHN \& HAYAT 1999; Pumain, Rozenblat \& Moriconi-Ebrard 1996). A synthetic image of the different forms of urban settlement in Europe has been accomplished through an ascending hierarchical classification which categorizes the regions according to the values of their density indicators and hierarchical rank (Fig. 2).

The three principal typologies of urban settlement proposed here are subdivided into two or three sub-types. This subdivision is not random, but reflects vast, relatively homogeneous regions within Europe. The characterisation of these types contains elements originally selected by JuILlard and NoNN (1976), extending on these from the point of view of detail and precision of description. For example, JUILlaRd and NONN distinguish between «Parisian», «Rhineland» and «peripheral» models of urbanization. This classification into three principal types of urban centres does not in any way precondition relative development capacity. 


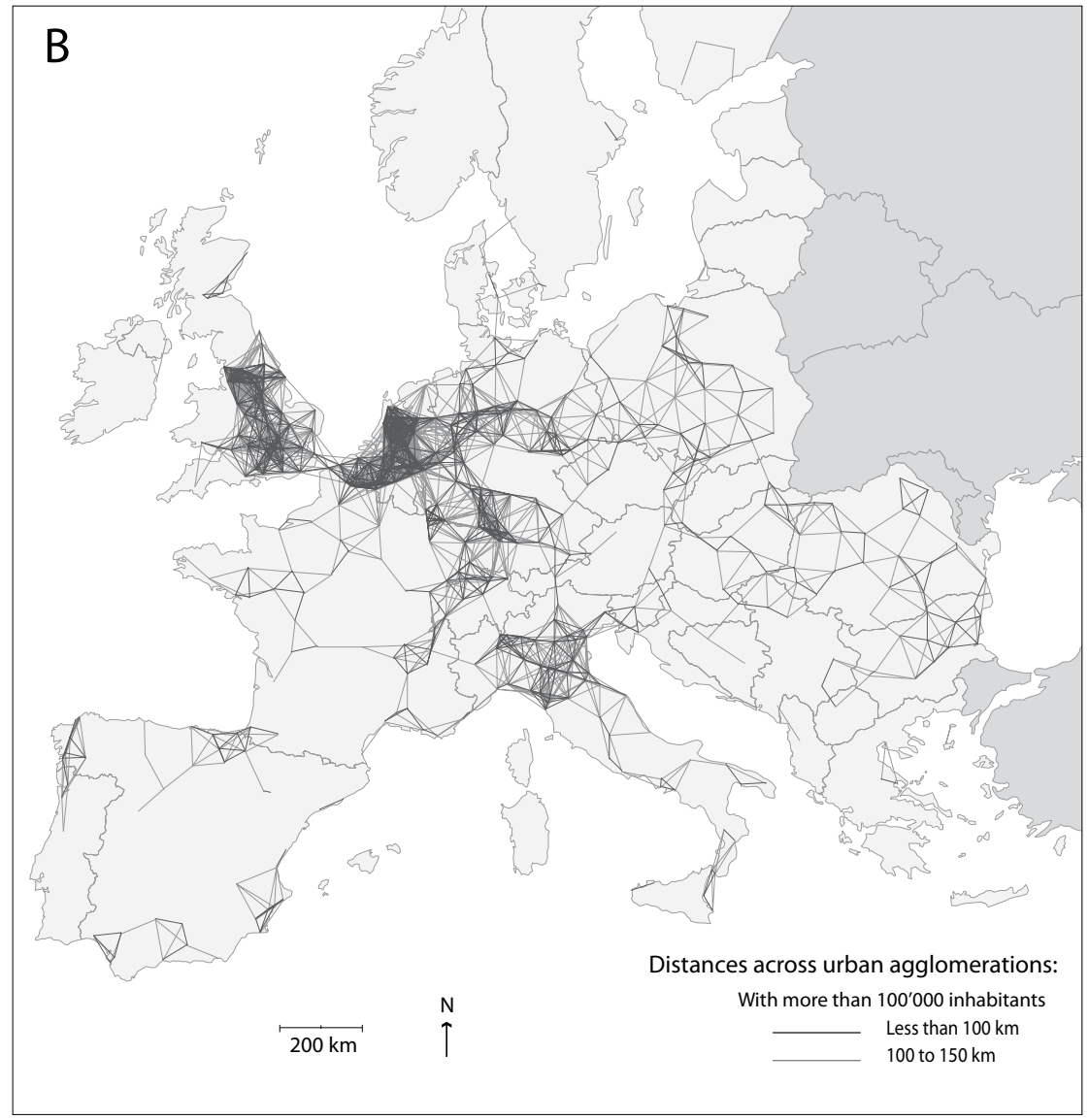

Fig. 1B: European urban framework according to cities with more than 100'000 inhabitants Europäisches Städtesystem nach Städten mit mehr als 100'000 Einwohnern

Trame urbaine européenne selon les villes de plus de 100'000 habitants

Data source: Fr. Moriconi-Ebrard, 1994; georeferencement, modelization, cartography: C. Rozenblat

Indeed, when these groups are compared to regional GDP or regional per capita GDP, no significant correlation is observed. Observations made by VANDERMOTTEN (2003: 27, Fig. 7) with regards the lack of a systematic relationship between national scales of pre-eminence and the level of interregional disparity within European countries, support this conclusion. Conditions between regions are highly variable, and the existence of a dense and only slightly hierarchically differentiated urban network should not be seen as a guarantee for economic development or territorial equity.

\subsection{Urban networks and regional development}

Despite the above-mentioned observations, dense and weakly hierarchically differentiated regions have been propagated since the end of the 1980 s as the benchmark for equity and performance (BENKO \& LIPIETZ 1992, 2000). Examples of high-performance networks of smaller towns - such as in the Lombardy, EmiliaRomagna or Prato Valley in the Tuscany (The Third Italy) - have often been described in this connection (Becattini 1987, 1992; Becattini \& Rullani 1995). However, it has also been pointed out that these examples are embedded in regional structures that are not easily transferable as they correspond to types of functional, institutional and cultural (even familial) links which are rooted in specifically local modes of socialization (VANDERMotTEN 2003). Furthermore, the duration of «success» of these innovative Italian centres does not appear to be destined to continue in the medium term 


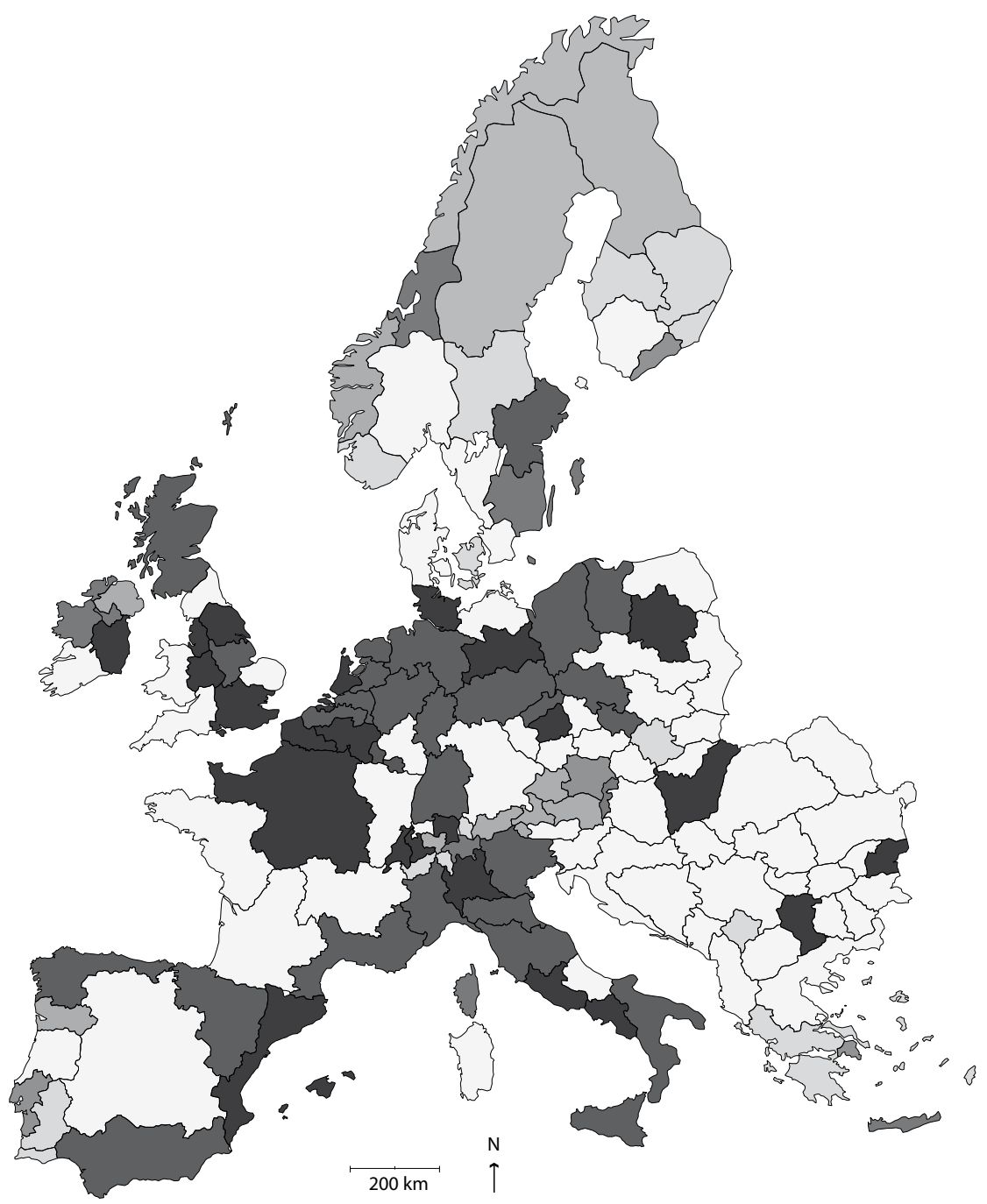

Types according to a hierarchical ascendant classification on following indicators: urbanisation rate, average distance across cities and three inequality indexes of cities size

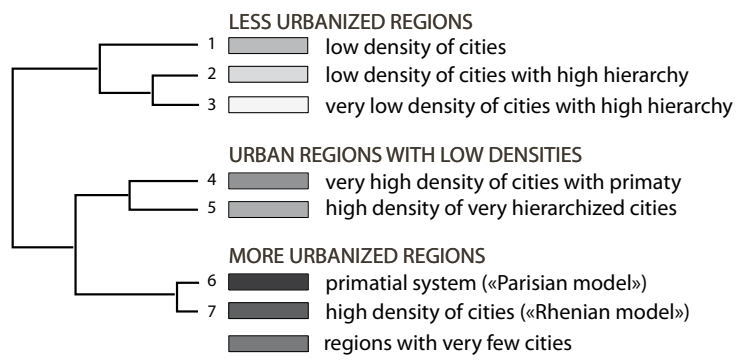

Fig. 2: Regional typology of urban structures

Regionale Typologie urbaner Strukturen

Typologie des systèmes urbains régionaux

Data source: Fr. Moriconi-EBRARD, 1994; georeferencement, statistics, cartography: C. Rozenblat 
as the metropolitanization of Milan today deploys centripetal forces of concentration of high-level functions throughout the Lombardy. The industrial networks of Lombardy as a whole, although achieving a degree of development in the past, appear to be experiencing difficulty in stabilising and enhancing development in the light of the technological progress of, and the performance achieved by, businesses concentrated in the revitalized Milan metropolitan area. This reflects a general tendency that may be observed throughout Europe, and particularly in France (Commerçon 1999; Gault 1989; Mirloup 2002). It is the result of an historical process of progressive adaptation of a system that was initially predicated on a certain rate of transportation speed and which has been transformed by an increasingly rapid distance effect (Pumain 1997, 2006). Moreover, barriers to exchange, which were constituted by political and socio-economic structures, are breaking down and interdependence is developing over greater distances.

The mutual influence of network dynamics raises the issue of the geographical scale at which interrelations between networks develop. This process gives rise to a largely constituent cohesion of the «boundaries» of the city and its influence. Three factors appear to dominate the development of such cohesion:

- geographical (topographical) proximity, which enables economies of agglomeration in each network;

- proximity within the network (topological), which encompasses previous processes, but which can also transcend geographical distance;

- the diversity of networks, which, at both local and global levels, enables the strengthening and renewal of networks.

At the local level, network economies shaped by topological proximity are part and parcel of the economies of agglomeration insofar as they are coupled with spatial proximity (topographical).

However, they can also transcend this process: intercity exchange networks have long existed (rare products, cottage industries, technical and social innovation, territorial organisation, empires) (BAIroch 1985; MumFORD 1961). Today, technological advances, especially in terms of travel and communication, have bolstered the mutual interdependence of cities. Consequently the power and the social and economic features of one city are directly confronted with those of other cities because of specialised interurban interaction which transposes codes, technological demands, and «cultures». These networks have accelerated the rate at which innovation, development and crises spread through city systems. Long-range networks also help strengthen each type of movement or activity through incorporation of new members who contribute, even at a distance, to the visibility and development of urban groups and local activities.

The position of each city in a system of cities depends largely on its ability to remain stable and to renew itself. These abilities depend on the propensity of its populations, groups and networks to drive or to adopt major innovations, and are heavily influenced by the dynamics of the city both past and present and by its historical, social and economic organisation (PUMAIN 1997). What differentiates one space from another is the specific arrangement of individual networks, which in turn organise the arrangement of different entities and functions at both local and distant scales. The dynamics of these two scales are intrinsically linked, even if no direct causal effects on their respective dynamics are produced by their interaction.

\section{Evaluation of polycentrism}

Very often, territorial policies are implemented at a single given level (e.g. intra- or inter-urban) without any real effort to take its repercussions at other geographical levels into account. A broad range of policies are applied by every national and regional government (Allain, Baudelle \& Guy 2003a; Faludi 2006; Hague \& KIRK 2002; JöNSSON, TÄGIL \& TÖRNQUIST 2000). In order to evaluate these, a typology of each of the different policies listed in the ESPON (EUROPEAN SPATIAL PlanNing Observation Network) 1.1.1 final report was specified (2005, Annex B). This typology, based on scales of application and kinds of product process, led to the definition of four categories (Fig. 3).

At the local scale, city-based policies (Fig. 3A), such as those implemented in Berlin and in major cities in Switzerland, Austria, France, Spain and the Netherlands, aim to dilute functions and decongest the centre in order to form multifunctional urban hubs rather than single-function satellites. The hope is to thereby uphold the economies of agglomeration generated by urban areas while avoiding the diseconomies of agglomeration by which they tend to be saturated. This involves not only the optimisation of transport networks, but also of activity location in order to ensure that every centre of the multi-polar agglomeration benefits from both a dynamic social fabric as well as a diversity necessary for its continuity (RUTHERFORD 2005; Schindegger \& TATZBerger 2002; ScotT 2001). Without a doubt, this is what constitutes the type of polycentrism most commonly implemented in Europe at the present under the auspices of Agenda 21 initiatives. While these latter result from awareness of the negative effects of urbanization, both personal and social, they are also the product of power interactions, both between the different levels of territorial 

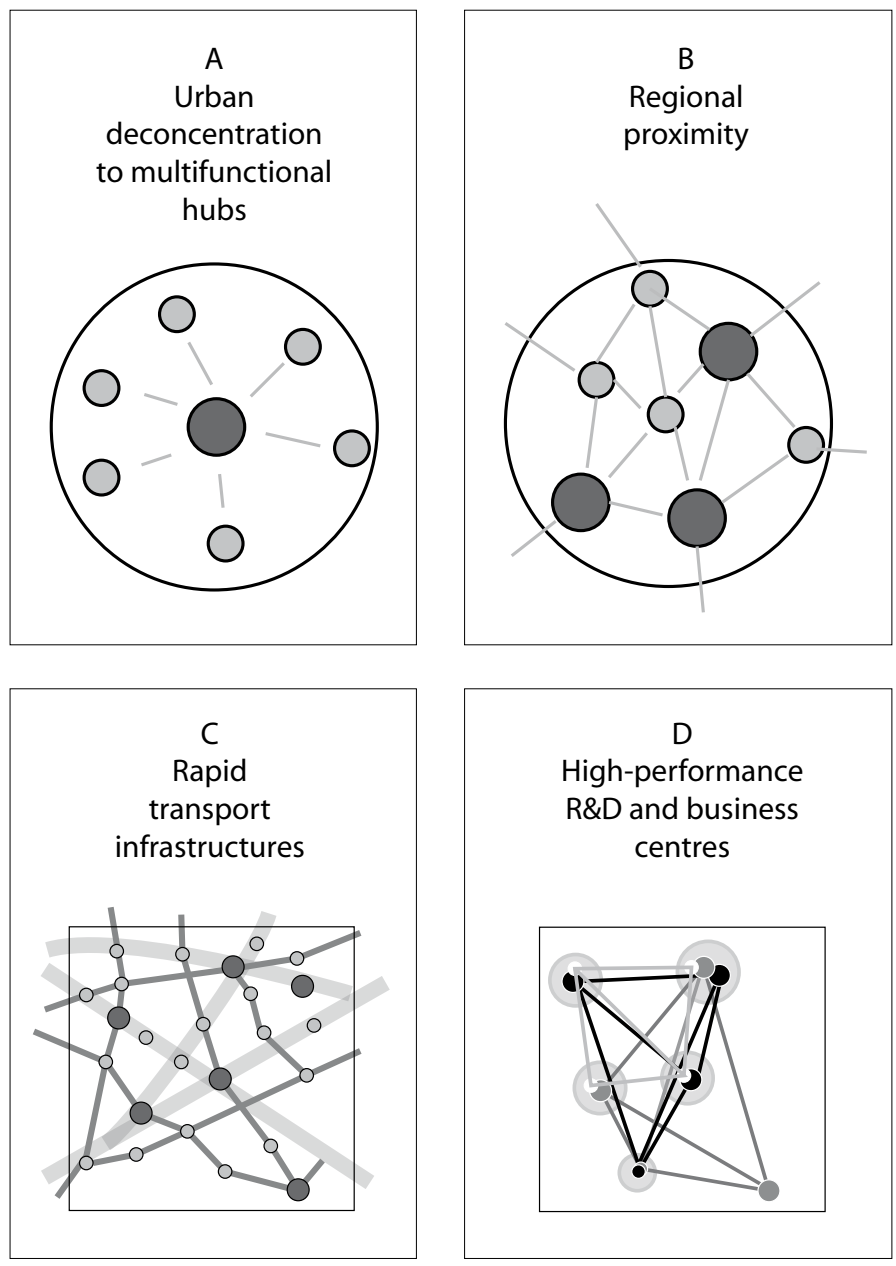

Fig. 3: Typology of urban development policies in Europe

Typologie der Stadtentwicklungspolitik in Europa

Typologie des politiques urbaines en Europe

C. Rozenblat

scale and, within a given level, between local administrations (Jouve \& LeFÈvre 2004). Facilitated by the decentralization of responsibility from the national to the local levels, the frequent result is a more effective concentration of power, capable of enabling better co-ordination of local policy making. This type of organization, however, often gives rise to problems of competition between different organs of government. Within strongly centripetal regions, the authority of the largest city is less problematical than is the case in dense and evenly diffused urban zones, where demographical equality hinders the emergence of a clearly identifiable leadership. The decentralization of power away from the national level and towards regional or urban levels very often exacerbates the lack of clarity about power hierarchies. More particularly, it sometimes tends to restrain collaboration between cities and their hinterlands - even though this is clearly beneficial.

At regional, or even national or international scales (Fig. 3B), neighbouring cities are encouraged to share facilities and cooperate in economic, administrative and cultural functions, as is the case in Switzerland, 
Portugal, Holland and France (through metropolitan cooperation contracts), for all facilities cannot be present in every location (especially airports and rare economic and cultural functions). This type of cooperation between neighbours is a particularly favourable factor in the development of regions possessing regular spatial networks. And it was in regions of exactly this type that the first initiatives were undertaken, notably in western France (Allain, BaUdelle \& GuY 2003a, 2003b; ReITel 2007). While it is wholly possible that the same could be implemented in Central Europe, where just such regular networks structure space (as in Silesia, Fig. 1), their implementation would appear to be more problematical elsewhere. By the same token, the experience of sharing - of airports for example - has been very variably appreciated. The establishment of «horizontal» links between cities of similar size should serve not only to improve the infrastructures of all partners, but also to connect mediumsize urban areas with those larger ones that constitute the interface with the international level. The proliferation of links at every scale of geographical scope (as is suggested by Fig. 1) can enable a reinforcement of the diversity of each regional territory, and thus encourage the diversity of a «multi-dependency» which would promote the robustness of regional systems with regard to their infrastructural, economic and social vulnerability. Thus, egalitarian networks of this type should not be established in opposition to large towns, but rather, in collaboration with them, developing strong infrastructural and socio-economic links between larger and smaller urban centres. This would allow regions to leverage their specific characteristics so as to spread their influence more widely.

At regional and national scales, national hubs are strengthened through transport infrastructure developments (Fig. 3C), primarily in emerging European countries like Slovenia and Estonia. Such national policies are frequently financed through structural aid funding with the purpose of breaking the vicious circle of depopulation, decrease in accessibility and decline in local economic activity. It is for this reason that priority is often accorded to the improvement of transport infrastructures in order to increase the attractiveness of peripheral regions (MeiJers, Romein \& HoppenbrouWER 2003; RIETVELD \& BRUINSMA 1998). By integrating certain regions more effectively into trans-European networks, the increase in transportation supply can, at the same time, facilitate the flight of certain activities towards major urban poles thanks to the economies of agglomeration they thus acquire. For those countries still backward in their development, the improvement of their integration is very often accomplished through the action of those of their regions which are located in an intermediary position with regard to European space (such as regional capitals). The overall result of such developments at the European scale is the increasing concentration of vectors of change along a number of principal axes: the European dorsal axis that stretches from the London basin to Lombardy being the most important of them. Centred, as it were, along the north-south trajectory of the River Rhine, forming a powerful ensemble grouping productive capacity and wealth, the European dorsal has inherited the ancient merchant networks that connected the Orient to the North Sea via Venice and Lombardy. The Seine-Saône-Rhône axis and that drawn along the line Moselle-Saône-Rhône vector important traffic flows of every kind. Other axes of European significance, though supporting less traffic stretch, for example, from the Benelux countries to the Basque Country via Paris, or from Cologne to Warsaw via Berlin. The extension of the European Union appears to have led to a reinforcement of the importance not only of the latter axis, but also of the central axes which interact with each other. European transport policies would thus seem to lead to a greater differentiation of European territory rather than to its homogenisation. On the other hand, they do, at the same time, increase its cohesion capability over long geographical distances.

At national, or even international, scales, high-performance business and R\&D (research and development) hubs have been established (Fig. 3D), for example in France, Holland and Switzerland - where «competitive poles» are defined in the spirit of the Lisbon perspective on the knowledge society. Imagined as a mixing of research, industry and education and training, the diversity of networks creates an «entropic» system in which interaction plays a multiplying role and serves as a source of renewal (through competition/cooperation) both at a local and a global scale (VAN DEN Berg, BRAun \& VAN Winden 2001). This is the distinguishing feature of simple, highly specialised urban «clusters» (such as «industrial zones»), which are essentially multidimensional, multiform and multi-scale. In the city, routine access to resources that are both specialised and diversified generates «security» («risk insurance»: VELTZ 2000) professed necessary for the development of the human population and their activities. Between cities, access to diversified and complementary resources contributes to their complementarity with distant resources, for example through the effect of spatial division of labour (AYDALOT 1986). Whether within or between cities, it is to be expected that different types of networks interlink, compete and support each other thereby improving themselves and each other (Rozenblat \& Cicille 2003). However, the assumption that industrial, education, training and research networks uphold and feed back into each other in a soley positive way is questionable. One can expect that - through the interaction between networks and through the domination of networks 
in socio-economic or communication structures - a number of networks impose their characteristics on others. More generally, through the reciprocal adaptation of different networks, levels of scale produce «attractive» infrastructures for newly emerging networks. Power networks provide mutual reinforcement at the decision-making level and in terms of their specific organisation. The importance of achieving a correct balance between the degree of diversity of network levels and the degree of convergence of those levels within unified common networks depends - when functioning inside given urban centres - on the maintenance of a strong capacity for reactivity and renewal, and - when functioning between urban centres - on the local visibility of those networks. The same is also true of national and regional territories whose institutional networks both «attract» and at the same time are strengthened by economic and social networks through language and identity, with the support and provision of the transport and communication networks which feed the «territory».

\section{Articulation of polycentric policy scales}

The urban system constitutes an attractive structure for new activities and supports diffusion of innovations, which in turn can lead to unequal urban development. In order to guide urban development, the appropriate authorities would need to pay attention to the different scales of effect of decisions made at different levels of power. Thus, at local and regional scales, the deconcentration of big cities (Fig. 3A) is primarily coordinated by municipalities which are organized and driven by regional authorities. Cooperation between closed cities (Fig. 3B) could be led by regional authorities, but not in a closed way. Inter-regional cooperation and share of infrastructures is essential from an infranational and cross-border point of view. For transportation planning (Fig. 3C), relays in terms of spatial and temporal connection imply a multi-modal coordination with vertical character incorporating national and regional companies. Examples of international, national and regional incentives exist which indicate the possibility of stimulating this creation of relay. In order to irrigate all the territory in a public service point of view, the regional level must impose some rules to the national and international one. At the opposite, in order to define some specialized clusters (Fig. 3D), the local and regional level is often not able to introduce hierarchies of priority due to the possible influence of local pressures. This restriction can lead to recentralisation of decision-making with redistribution of functions and locations between cities. In Switzerland, research centres (including those supported at Cantonal level) were redefined at Federal level over a period of a few years in view of creating Centres of
Excellence. This led to a top-down redistribution of research teams and a concentration of investments. In Spain, statistical data collection of regional agencies is now redefined at least for nomenclatures at the national level in order to compare regional developments (comparisons which had become impossible).

Vertical subsidiary between geographical scale become more and more relevant in planning actions and this reflection must be updated for each action and for each kind of concerned actors. For example, from the view point of sustainable issues, if environmental or social segregation is to be applied at city and local level, social, economical and research subjects at national and continental scale would be more relevant than at lower scales due to the far-reaching network character of the former (KEINER \& KIM 2007). A European policy could be more active to invest and define research centre in coordination with local actors than the local centre itself. Of course, European policies should be context-sensitive and normative rules should be avoided. Dialogue platforms are necessary between horizontal actors (e.g. for interregional coordination) as well as between vertical levels (e.g. for a polycentrism multi-scale approach). In fact, for an efficient effect, an international centre supported by national or international funds can be located in an appropriate quarter to balance local segregation or mobility. At the opposite, a local initiative to create, for example, an economic centre could be linked with regional, national or international strategy in the specialized field. Although these forms of collaboration seem so obvious in theory, in reality their implementation appears problematic, as may be seen in the lack of policy coordination between regions and cities (like in France), between autonomous ports and cities (like in Genes or in Naples) and between national authorities and local ones (like in Marseille in connection with the Euromediterranée project) (RozEnBlat et al. 2004).

Competition between territories (closed or distant) is often unnecessary because of the possibilities provided by spatial interactions. Although every activity cannot be present everywhere, services, infrastructures and developed zones generate positive effects in all accessible territories. In fact, the four different kinds of polycentric organization can reinforce each other. For example, the choice of a good location for a new specialized economic activity park can promote the creation of cultural, leisure or shopping infrastructures elsewhere. Such a choice necessarily implies international coordination to simultaneously develop the activity centre itself along with transportation infrastructures at local, regional and international scales, local control of real-estate and housing and a long-term policy of social integration based on the diversification of employment that is supported at 
national and regional levels. All of this serves to incite businesses to invest here and not elsewhere (Jouve \& LEFÈVRE 2002, 2004; LegaLES 2002). Such coordination can only work if local actors are prepared to take the preferences and ambitions of their neighbouring populations positively into account and if they have a clear understanding both of the city system in which they are embedded and of the system of cities as a whole (Pumain 1997).

\section{Conclusion}

Polycentrism is put forward - virtually as an ideology - almost exclusively at local or narrow regional levels, concerning mid-sized urban centres as opposed to metropolises. In this regard, the national scale is considered to be inexistent, whereas we have demonstrated the extent to which it still plays a significant role in regional dynamics. It is emphasised, that it is the large cities which bear the lion's share of this national development through the continuous extension of their trans-national networks. Issues of the appropriate territorial levels in decision-making are pertinent at this juncture, given that the local authorities which decide upon the location of poles of competitiveness usually only pay attention to a particular aspect that needs to be accommodated and generally ignore the networks that are indispensable to its prosperity and value. Indeed, the economies of agglomeration afforded by large urban centres have, since the end of the 1990s, again become growth factors, particularly with regard to the multinational companies which represent two-thirds of all international trade and an ever-increasing part of global investment. It does appear that globalization (along with the «continentalization» that it induces, particularly in Europe) favours the upper part of the urban hierarchy, but it is shown herein that - and specifically with regard to multinational businesses - mid-scale cities and regions play a major role in this process - even if that role is only an indirect one - by acting as spatial mediators or staging posts (Rozenblat \& PUMAIN 2007). Without bringing together all possible functions - as the great political and economic capitals do - specializations develop throughout the fabric of European cities and regions, thus underlining the multi-level complexity of the continental system. Without a doubt, it is through this complexity of levels that decision-makers will be able to intervene in a way that is pertinent to each specific regional, urban and national context in Europe.

\section{Bibliography}

Allain, R., Baudelle, G. \& C. Guy (dir.) (2003a): Le polycentrisme, un projet pour l'Europe. - Rennes: Presses Universitaires de Rennes.
Allain, R., Baudelle, G. \& C. Guy (dir.) (2003b): Le polycentrisme. Une ambition nouvelle pour l'aménagement du territoire. - Rennes: Presses Universitaires de Rennes.

Aydalot, P. (éd.) (1986): Milieux innovateurs en Europe. - Paris: Groupement de Recherche Européen sur les Milieux Innovateurs (GREMI).

BaIroch, P. (1985): De Jéricho à Mexico: Villes et économies dans l'Histoire. - Paris: Editions Gallimard.

Becattini, G. (éd.) (1987): Mercato e forze locali: il distretto industriale. - Bologna: Il Mulino.

Becattini, G. (1992): Le district marshallien: une notion socio-économique. - In: BeNKo, G. \& A. LIPIETZ (éds): Les régions qui gagnent. Districts et réseaux: les nouveaux paradigmes de la géographie économique. - Paris: Presses Universitaires de France: 35-55.

Becattini, G. \& E. Rullani (1995): Système local et marché global. Le district industriel. - In: RALLET, A. \& A. TORre (éds): Economie industrielle et économie spatiale. - Paris: Economica: 171-192.

Benko, G. \& A. Lipietz (éds) (1992): Les régions qui gagnent. Districts et réseaux: les nouveaux paradigmes de la géographie économique. - Paris: Presses Universitaires de France.

Benko, G. \& A. Lipietz (éds) (2000): La richesse des régions: la nouvelle géographie socioéconomique. - Paris: Presses Universitaires de France.

Castells, M. (1998): La société en réseau. - Paris: Fayard.

Cattan, N., Pumain, D., Rozenblat, C. \& T. SaintJulien (1999): Le système des villes européennes. - Paris: Anthropos.

Christaller, W. (1933): Central places in Southern Germany. - Englewood Cliffs: Prentice Hall.

Commerçon, N. (dir.) (1999): Villes de transition. - Paris: Anthropos.

European Spatial Planning Observation Network - ESPON (2005): Potentials for polycentric development in Europe. - Final Report 1.1.1, Annex B: The application of polycentricity in European countries; http://www.espon.eu/mmp/online/website/content/ projects/259/648/index_EN.html.

European Spatial Planning Observation Network - ESPON (2006): Spatial scenarios and orientations in relation to the ESDP and cohesion policy. - Third Interim Report 3.2; http://www.espon.eu/mmp/online/ website/content/projects/260/716/index_EN.html.

FALUdi, A. (2004): A polycentric process for a polycentric Europe. - GAP-Working Paper Series, Nijmegen School of Management.

FALUdI, A. (2006): From European spatial development to territorial cohesion policy. - Regional Studies 40, 6 .

FALUdi, A. \& B. WATERHout (2002): The making of the European spatial development perspective. - London: Routledge.

Gault, M. (1989):Villes intermédiaires pour l'Europe? - Paris: Syros-Alternatives. 
Hague, C. \& K. KIRK (2002): Polycentricity scoping study. - Edinburgh: School of the Built Environment. Jönsson, C., TÄGIL, S. \& G. TöRnQUist (2000): Organizing European space. - London: SAGE.

Jouve, B. \& C. Lefèvre (eds) (2002): Local power, territory and institutions in European metropolitan regions. - The Cass series in regional and federal studies 6, London: Frank Cass.

Jouve, B. \& C. Lefèvre (éds) (2004): Horizons métropolitains. - Lausanne: Presses polytechniques et universitaires romandes.

Juillard, E. \& H. NonN (1976): Espaces et régions en Europe occidentale. - Paris: Centre national de la recherche scientifique - CNRS.

KeIner, M. \& A. KIM (2007): Transnational city networks for sustainability. - In: European Planning Studies 15, 10: 1369-1395.

KüHN, F. \& S. HAYAT (1999): Indicateurs de qualité de service et faits marquants sur 22 réseaux de transport urbain en Europe. - Arcueil: Institut National de Recherche sur les Transports et leur Sécurité INRETS.

LEGALES, P. (2002): European cities, social conflicts and governance. - Oxford: Oxford University Press.

Meijers, E.J., Romein, A. \& E. Hoppenbrouwer (2003): Planning polycentric urban regions in North West Europe. - Delft: Delft University Press.

Mirloup, J. (dir.) (2002): Régions périmétropolitaines et métropolisation. - Oréans: Presses universitaires d'Orléans.

Moriconi-EBrard, F. (1994): Geopolis: pour comparer les villes du monde. - Paris: Anthropos.

MuMFord, L. (1961): The city in history: its origins, its transformations and its prospects. - New York: Harcourt, Brace \& World.

Offner, J.-M. \& D. Pumain (dir.) (1996): Réseaux et territoires: significations croisées. - La Tour d'Aigues: Editions de L'Aube.

Perroux, F. (1955): La notion de pôle de croissance. L'économie au $\mathrm{XX}^{\mathrm{e}}$ siècle. - Paris: Presses Universitaires de France.

Pumain, D. (1997): Pour une théorie évolutive des villes. - In: L'Espace Géographique 2:119-134.

Pumain, D. (ed.) (2006): Hierarchy in natural and social sciences. - Methodos Series 3, Dordrecht: Springer.

Pumain, D. \& C. Rozenblat (1999): The regional patterns of the European urban system. - In: VAN Der Leeuw, S.E. \& L. Garenne-Marot (eds): Policy relevant models of the natural and anthropogenic dynamics of degradation and desertification and their spatio-temporal manifestations; volume 5, tome 1: A multiscalar investigation into the dynamics of land abandonned in southern France. - Draft final report of the ARCHEOMEDES II research project, submitted to the DG XII of the European commission: 1127.

Pumain, D., Rozenblat, C. \& F. Moriconi-Ebrard
(1996): La trame des villes en France et en Europe. - In: Pumain, D. \& A. Chenu (dir.): Données urbaines 1. - Paris: Anthropos.

ReITEL, B. (2007): Les agglomérations transfrontalières: des systèmes urbains en voie d'intégration? Les espaces urbains de la «frontière» du territoire français. - In: Geographica Helvetica 62, 1: 5-15.

RIETVELD, P. \& F. BRUINSMA (1998): Is transport infrastructure effective? Transport infrastructure and accessibility: impacts on the space economy. - Berlin: Springer.

Rozenblat, C. (1995): Tissu d'un semi de villes européennes. - In: Mappemonde 4: 22-27; http://www.mgm. fr/PUB/Mappemonde/Mappe495.html.

Rozenblat, C. (2004): Tissus de villes. Réseaux et systèmes urbains en Europe. - Habilitation à diriger des recherches, HDR; http://www.mgm.fr/ARECLUS/ page_auteurs/rozenblat.html.

Rozenblat, C. \& P. Cicille (2003): Les villes européennes: analyse comparative. - Paris: La Documentation française. (2004: German translation: Die Städte Europas: Eine vergleichende Analyse. - Bonn: Bundesamt für Bauwesen und Raumordnung).

Rozenblat, C., Cattedra, R., Chapelon, L., Joly, O., Lemarchand, A., Lavaud-Letilleul, V., Martell, H., Rodrigues-Malta, R. \& P. Cicille (2004): Comparer les villes portuaires en Europe. - Rapport pour l'Institut de recherche stratégique industriel et technologique (IRSIT), Le Havre.

Rozenblat, C. \& D. Pumain (2007): Firm linkages, innovation and the evolution of urban systems. - In: Taylor, P.J., Derudder, B., Saey, P. \& F. Witlox (eds): Cities in globalization. Practices, policies and theories. - London: Routledge: 130-156.

RUTHERFORD, J. (2005): Networks in cities, cities in networks: Territory and globalisation intertwined in telecommunications infrastructure development in Europe. - Urban Studies 42, 13: 2389-2406.

Sassen, S. (1991): The global city: New York, London, Tokyo. - Princeton: Princeton University Press.

Schindegger, F. \& G. TAtzBerger (2002): Le polycentrisme - une vision européenne pour le développement du territoire. - Wien: Österreichisches Institut für Raumplanung.

Scotт, A. (ed.) (2001): Global city-regions: Trends, theory, policy. - Oxford: Oxford University Press

VAN DEN BERG, L., BRAUn, E. \& W. vAN Winden (2001): Growth clusters in European cities: An integral approach. - In: Urban Studies 38, 1: 185-205.

VANDERMOTTEN, C. (2003): Le polycentrisme dans une perspective historique. - In: Allain, R., Baudelle, G. \& C. GuY (dir.): Le polycentrisme, un projet pour l'Europe. - Rennes: Presses Universitaires de Rennes: 17-28.

Veltz, P. (2000): Le nouveau monde industriel. - Paris: Editions Gallimard. 


\begin{abstract}
European urban polycentrism: a multiscale typology

Several publications of the European Spatial Planning Observation Network (ESPON) suggest that one should be aiming at a polycentric urban system, albeit one which does not unambiguously display properties of territorial development (VANDERMOTTEN 2003). Focusing on concentration processes and implications of urban policies, the article draws attention to those regional processes (topographic) and urban networks (topologic) destined to play the double role of catalyst and diffuser of innovations in a diversified European territory. It is argued that various spatial scales and a range of different perceptions of polycentrism be taken into consideration. It is felt that only through the articulation of these differences will the relevant processes and networks be able to function optimally within a context where the interrelations of urban governance are adapted to each territory.
\end{abstract}

Keywords: urban systems, Europe, urban framework, regions, polycentrism

\section{Résumé: Polycentrisme urbain en Europe: une typologie multi-échelle}

Plusieurs travaux de l'Observatoire en Réseau de l'Aménagement du Territoire Européen (ORATE) suggèrent de s'orienter vers un système urbain polycentrique, mais qui ne montre pas en soi de propriétés évidentes de développement territorial (VANDERMOTTEN 2003). Partant des processus de concentration et des suggestions de politiques urbaines, cet article propose une réflexion sur les processus à l'échelle régionale (topographiques) et à l'échelle des réseaux urbains (topologiques) susceptibles de jouer le double rôle de catalyseur et de diffuseur des innovations dans un territoire européen diversifié. L'article suggère de distinguer différentes échelles spatiales et différentes visions du polycentrisme. Ce n'est que dans leur articulation qu'elles pourront être pleinement efficaces dans une contextualisation des subsidiarités de gouvernance urbaine adaptées à chaque territoire.

Mots-clés: systèmes urbains, Europe, trame urbaine, régions, polycentrisme

\section{Zusammenfassung: Städtischer Polyzentrismus Europas: eine mehrskalige Typologie}

Mehrere Publikationen des European Spatial Planning Observation Network (ESPON) empfehlen, sich nach einem polyzentrischen Stadtsystem zu orientieren, was jedoch in sich keine offensichtlichen Eigenschaften der Raumentwicklung zeigt (VANDERMOTTEN 2003). Ausgehend von Konzentrationsprozessen und Empfehlungen der Stadtpolitik wird eine Reflexion der Prozesse im regionalen (topographischen) Massstab sowie im topologischen Massstab der Städtenetze vorgeschlagen. Diese sollen eine doppelte Rolle als Katalysator und Verbreiter der Innovation in einem diversifizierten europäischen Raum spielen. Es wird empfohlen, verschiedene räumliche Massstäbe und Visionen des Polyzentrismus zu unterscheiden. Nur dadurch können die relevanten Prozesse und Netzwerke optimal funktionieren in einem Kontext, in dem die Beziehungen der städtischen Steuerung (urban governance) für jedes Territorium neu entwickelt werden müssen.

Schlüsselwörter: urbane Systeme, Europa, urbanes Raster, Regionen, Polyzentrismus

Prof. Dr. Céline Rozenblat, Institut de géographie, Université de Lausanne, Quartier Dorigny, Bâtiment Anthropole, CH-1015 Lausanne, Suisse.

e-mail: celine.rozenblat@unil.ch

Manuskripteingang/received/manuscrit entré le 17.12.2008

Annahme zum Druck/accepted for publication/accepté pour l'impression: 5.9.2009 